\title{
Respiration, microbial biomass and nutrient availability are influenced by previous and current soil water content in plant residue amended soil
}

\author{
Yanchen Zhang ${ }^{1}$, Petra Marschner ${ }^{1 *}$ \\ ${ }^{1}$ School of Agriculture, Food and Wine. The University of Adelaide, South Australia, 5005, Adelaide, Australia. \\ *Corresponding author: petra.marschner@adelaide.edu.au
}

\begin{abstract}
:
The aim of this study was to determine how soil respiration, microbial biomass and nutrient availability after the first and second plant residue addition are influenced by soil water content and number of days between rewetting of dry soil and second residue addition. A loamy soil was amended with low $\mathrm{C} / \mathrm{N}$ ratio (L) or high $\mathrm{C} / \mathrm{N}$ ratio $(\mathrm{H})$ plant residues and then maintained at $10 \%$ or $50 \%$ water holding capacity (WHC) for 10 days after which the soil at $10 \% \mathrm{WHC}$ was rapidly rewetted to $50 \% \mathrm{WHC}$. A second residue with a different $\mathrm{C} / \mathrm{N}$ ratio than the first was added one, two or five days after rewetting. Lower water content (10\% WHC) during the first 10 days reduced respiration and microbial biomass. After day 10, MBN increased with number of days after rewetting. After the second residue addition, respiration rate in the first three to four days and available $\mathrm{N}$ after two days were higher when residue was added five days after rewetting compared to one day. But MBN was higher in treatments with residues added one day after rewetting compared to amendment after five days. The water content in the first 10 days had little effect on microbial biomass and nutrient availability after the second residue addition. We conclude that soil respiration, $\mathrm{N}$ mineralisation and immobilisation are influenced by the interval between plant residue additions, particularly in rewet soil.
\end{abstract}

Keywords: Microbial biomass, nutrient availability, plant residue addition, soil respiration, soil water content

\section{Introduction}

Global warming is predicted to result in increasing drought frequency and intensity, which will influence soil water content (IPCC, 2007). A key aspect of sustainable food production (Scotti et al., 2015) is supply of nutrients to crops through decomposition of plant residues by soil microorganism (Power, 2010). Low soil water content limits plant residue decomposition as it restricts water availability and nutrient diffusion, and at very low water content, may draw water 
out of the cells (Schimel et al., 2007). Rapid rewetting of dry soil has been shown to result in a flush of respiration and available nutrients (Birch, 1958). The flush of available nutrients after rewetting of dry soil is due to a sudden increase in organic substrates which are then mineralised by the microbial biomass (Borken and Matzner, 2009).

Decomposition of organic residues is also influenced by residue properties such as $\mathrm{C} / \mathrm{N}$ ratio (Heal et al., 1997). Many studies have shown that residues with low $\mathrm{C} / \mathrm{N}$ ratio are decomposed rapidly and lead to net $\mathrm{N}$ mineralization as they satisfy the $\mathrm{N}$ demands of microbes (Hadas et al., 2004). However, in agricultural and natural ecosystems, plant residues with different $\mathrm{C} / \mathrm{N}$ ratio may be added to soil over time. Studies in our group showed that nutrient availability and microbial biomass after the second residue addition are influenced by the properties of the previously added residue, which is referred as legacy effect (Marschner et al., 2015; Nguyen et al., 2016). For example, $\mathrm{N}$ availability after addition of low $\mathrm{C} / \mathrm{N}$ residue is lower if it follows high $\mathrm{C} / \mathrm{N}$ residue than if added to previously unamended soil. This legacy effect occurs because in the former case, soil microbes decompose not only the freshly added low $\mathrm{C} / \mathrm{N}$ reside, but also the high $\mathrm{C} / \mathrm{N}$ residue left in the soil from the previous amendment. Recently, Zhang and Marschner (2016) found that the legacy effect of the first residue added was not influenced by the number of drying and rewetting events between first and second residue addition. On the other hand, respiration, microbial biomass and nutrient availability in plant residue amended soil were much lower at $10 \%$ water holding capacity than at 50\% WHC (Zhang and Marschner, 2017). In Nguyen et al. (2016), the legacy effect decreased with time between first and second residue addition (10, 20 or 30 days) and in Zheng and Marschner (2017), the legacy effect decreased with amendment rate of the first residue. These results suggest that extent of the legacy effect is influenced by the amount of the first residue left in the soil when the second residue is added.

In the field, soil water content may vary between residue additions and residues can be added at different times after rewetting. The aims of this study were to determine how soil respiration, microbial biomass and nutrient availability after the first and second residue addition are influenced by (i) soil water content between first and second amendment (10 and 50\% WHC), and (ii) number of days between rewetting of dry soil and second residue addition (1, 2, 5 days). We hypothesised that the legacy effect of the first residue added will be greater (i) when the soil water content between first and second residue addition is low, and (ii) if the second residue is added one day after rewetting compared to after two or five days.

\section{Materials and Methods}

\subsection{Soil and plant residues}

A loamy soil was collected in early spring 2015 from 0 to $10 \mathrm{~cm}$ depth in Urrbrae, South Australia (Longitude $138^{\circ} 38^{\prime} 3.2^{\prime \prime}$ E, Latitude $34^{\circ} 58^{\prime} 0.2^{\prime \prime} \mathrm{S}$ ) from an area that had been under permanent pasture for more than 80 years. This site is in a semi-arid area and has a Mediterranean climate with cool, wet winters and hot, dry summers. The soil is a Red-brown Earth according to Australian soil classification (Isbell, 2002) and classified as Rhodoxeralf in US Soil Taxonomy. Soil was collected along a randomly selected central 
transect in three $2 \times 2 \mathrm{~m}$ plots which were at least $10 \mathrm{~m}$ apart. In each sampling plot, after removal of plants and surface litter five samples of the topsoil $(0-10 \mathrm{~cm})$ were taken and sieved to less than $2 \mathrm{~mm}$ followed by air-drying in a fan-forced oven at 40 ${ }^{\circ} \mathrm{C}$. In southern Australia, top soils are often heated to $40{ }^{\circ} \mathrm{C}$ and higher temperatures on sunny summer days. Soil from all sampling points was mixed before starting the experiment. The soil properties are: $22 \%$ sand, $60 \%$ silt, $18 \%$ clay, maximum water capacity (WHC) $371 \mathrm{~g} \mathrm{~kg}^{-1}, \mathrm{pH}$ (1:5) 5.6, EC (1:5) $0.1 \mathrm{dS} \mathrm{m}^{-1}$, total organic $\mathrm{C} 17 \mathrm{~g} \mathrm{~kg}^{-1}$, total organic $\mathrm{N} 1.5 \mathrm{~g} \mathrm{~kg}^{-1}$, bulk density $1.3 \mathrm{~g} \mathrm{~cm}^{-1}$, available P 10 $\mathrm{mg} \mathrm{P} \mathrm{kg}{ }^{-1}$ and available $\mathrm{N} 15 \mathrm{mg} \mathrm{N} \mathrm{kg}^{-1}$.
Two types of plant residues were used: young faba bean (Vicia faba L.) as low $\mathrm{C} / \mathrm{N}$ ratio residue (L), and mature wheat straw (Triticum aestivum L.) as high $\mathrm{C} / \mathrm{N}$ ratio residue $(\mathrm{H})$ (Table 1$)$. These two plant species are typical crops in Southern Australia and often follow each other in crop rotations. The residues were dried at $40{ }^{\circ} \mathrm{C}$ in a fan-forced oven, finely ground and sieved to $0.25-2$ $\mathrm{mm}$ particle size. Compared to $\mathrm{H}, \mathrm{L}$ had five to ten times higher total $\mathrm{N}$, total $\mathrm{P}$, available $\mathrm{N}$ and $\mathrm{P}$ and two-fold higher water extractable $\mathrm{C}$ concentration, but lower $\mathrm{C} / \mathrm{N}$ and $\mathrm{C} / \mathrm{P}$ ratios (Table 1).

Table 1. Total organic C, N, P, C/N ratio and C/P ratio, available $\mathrm{N}$ and $\mathrm{P}$, water-extractable $\mathrm{C}$, and $\mathrm{pH}$ of low $\mathrm{C} / \mathrm{N}$ (young faba bean) and high $\mathrm{C} / \mathrm{N}$ (wheat straw) residues $(\mathrm{n}=4)$. Different lower case letters indicate significant differences among low and high $\mathrm{C} / \mathrm{N}$ ratio residues $(P \leq 0.05)$.

\begin{tabular}{lcc}
\hline Property & Low C/N & High C/N \\
\hline Total organic C $\left(\mathrm{g} \mathrm{kg}^{-1}\right)$ & 374 & 418 \\
Total N $\left(\mathrm{g} \mathrm{kg}^{-1}\right)$ & $22.9^{\mathrm{b}}$ & $4.9^{\mathrm{a}}$ \\
Total P $\left(\mathrm{g} \mathrm{kg}^{-1}\right)$ & $6.5^{\mathrm{b}}$ & $0.7^{\mathrm{a}}$ \\
$\mathrm{C} / \mathrm{N} \mathrm{ratio}$ & $16^{\mathrm{a}}$ & $86^{\mathrm{b}}$ \\
$\mathrm{C} / \mathrm{P}$ ratio & $58^{\mathrm{a}}$ & $643^{\mathrm{b}}$ \\
Available N $\left(\mathrm{mg} \mathrm{kg}^{-1}\right)$ & $487^{\mathrm{b}}$ & $87^{\mathrm{a}}$ \\
Available P $\left(\mathrm{mg} \mathrm{kg}^{-1}\right)$ & $247^{\mathrm{b}}$ & $30^{\mathrm{a}}$ \\
Water extractable C $\left(\mathrm{g} \mathrm{kg}^{-1}\right)$ & $92^{\mathrm{b}}$ & $54^{\mathrm{a}}$ \\
pH $(1: 10)$ & 6.2 & 6.3 \\
\hline
\end{tabular}

\subsection{Experimental design}

Before the start of the experiment, the air-dried soil was moistened to $50 \%$ of maximum WHC and incubated for 10 days at $22-23{ }^{\circ} \mathrm{C}$ in the dark at to activate the soil microbes and stabilise soil respiration. This water content was selected based on previous studies that showed that microbial activity is maximal at $50 \%$ WHC in this soil (Marschner et al., 2015). After pre-incubation, the soil was either kept at $50 \%$ WHC or dried in a fan-forced oven at $40{ }^{\circ} \mathrm{C}$ to $10 \%$ WHC. The low water content $(10 \%$ WHC) was selected because in Xue et al, 2016 with the same soil, respiration and microbial biomass were much lower than with $50 \%$ WHC, but still detectable. Half of the soil at each water content was amended with $\mathrm{H}$ at $10 \mathrm{~g}$ $\mathrm{kg}^{-1}$, the other half with $\mathrm{L}$. After 10 days, the soil at $10 \% \mathrm{WHC}$ was rewet to $50 \% \mathrm{WHC}$, whereas the water content of the soil at $50 \%$ WHC was kept as 
it was in the first 10 days. All soils were maintained at $50 \%$ until the end of the experiment. The second residue, which had a different $\mathrm{C} / \mathrm{N}$ ratio than the first [L after $\mathrm{H}$ (HL) or $\mathrm{H}$ after $\mathrm{L}(\mathrm{LH})$ ], was added 1, 2 and 5 days after rewetting. We refer to days after rewetting for simplicity although soil was not rewet in treatments that was kept at 50\% WHC in the first 10 days. Treatment names refer to order in which residues were added and the water content in the first 10 days, i.e. LH-10 (low followed by high $\mathrm{C} / \mathrm{N}$ residue at 10\% WHC), LH-50 (low followed by high $\mathrm{C} / \mathrm{N}$ residue at $50 \% \mathrm{WHC}$ ), HL-10 (high followed by low $\mathrm{C} / \mathrm{N}$ residue at $10 \% \mathrm{WHC}$ ) and HL-50 (high followed by low $\mathrm{C} / \mathrm{N}$ residue at $50 \% \mathrm{WHC}$ ). For each residue treatment, the second residue was added 1, 2, or 5 days after rewetting on day 10 .

The residues were thoroughly mixed with the soil, then $30 \mathrm{~g}$ dry soil equivalent was filled into the PVC cores with $3.7 \mathrm{~cm}$ diameter and $5 \mathrm{~cm}$ height with a nylon mesh base $(7.5 \mu \mathrm{m})$, Australian Filter Specialist and packed to a bulk density of $1.3 \mathrm{~g}$ $\mathrm{cm}^{-1}$. The cores were placed individually into $1 \mathrm{~L}$ jars with gas-tight lids equipped with septa to allow quantification of the headspace $\mathrm{CO}_{2}$ concentration as described below. The jars were incubated in the dark at $22-23{ }^{\circ} \mathrm{C}$. Soil moisture (10\% or $50 \%$ of WHC at the first 10 days and $50 \%$ of WHC after rewet) was maintained by checking the water content every few days by weighing and adding reverse osmosis (RO) water if necessary. Soil respiration was measured daily. Soil cores were destructively sampled two and 10 days after the first residue addition, one day before the second residue addition, and two and 10 days after the second residue addition. Soil samples were analysed for available $\mathrm{N}$ and $\mathrm{P}$, microbial biomass $\mathrm{N}$ and $\mathrm{P}$. For each sampling time and treatment there were four replicates, giving a total number of 176 cores.

\subsection{Measurements}

Soil analyses were carried out as described in Zhang and Marschner (2016). Briefly, soil texture was determined according to the rapid texture analysis (Chaudhari et al., 2008; Kettler et al., 2001). Maximum soil water holding capacity was measured using a sintered glass funnel connected to a $100 \mathrm{~mm}$ water column $\left(\psi_{\mathrm{m}}=-10 \mathrm{kPa}\right)$. Soil $\mathrm{pH}$ and EC were measured in a 1:5 (w/v) soil to reverse osmosis (RO) water ratio after 1 hour shaking at $25^{\circ} \mathrm{C}$. Total organic carbon of soil and plant residues was measured according to Walkley and Black (1934) and total nitrogen was measured using the Kjeldahl method followed by colorimetric measurement as described in Bremmer and Mulvaney (1982). Soil and plant residues were digested with a mixture of $\mathrm{HNO}_{3}$ and $\mathrm{HClO}_{4}$, to determine total $\mathrm{P}$. Total $\mathrm{P}$ in the extract was measured by the phosphovanadomolydate method. Water extractable organic carbon was extracted by shaking $1 \mathrm{~g}$ residue with $30 \mathrm{ml}$ RO water for 1 hour. Then the extract was centrifuged at $3000 \mathrm{rpm}$ for $10 \mathrm{~min}$ and filtered through a Whatman\#42 filter paper. The organic $\mathrm{C}$ in the extract was determined after $\mathrm{K}_{2} \mathrm{Cr}_{2} \mathrm{O}_{7}$ and $\mathrm{H}_{2} \mathrm{SO}_{4}$ oxidation by titration with acidified $\left(\mathrm{NH}_{4}\right)_{2} \mathrm{Fe}\left(\mathrm{SO}_{4}\right)_{2} \cdot 6 \mathrm{H}_{2} \mathrm{O}$.

Soil respiration was measured daily by quantifying the $\mathrm{CO}_{2}$ concentration in the headspace of the jars using a Servomex 1450 infra-red analyser (Servomex Group, Crowborough, UK) as described in Setia et al. (2011). Available N (ammonium and nitrate) concentration was measured after 1 hour end-over-end shaking with $2 \mathrm{M} \mathrm{KCl}$ at a $1: 5$ soil to extractant ratio. Ammonium-N was measured after Willis et al. (1996). Nitrate-N was determined as described in Miranda et al., (2001). Available P was extracted by the anion exchange resin method 
(Kouno et al., 1995), the $\mathrm{P}$ concentration was determined colorimetrically (Murphy and Riley, 1962).

Microbial biomass nitrogen (MBN) were determined by chloroform fumigation-extraction with $0.5 \mathrm{M} \mathrm{K}_{2} \mathrm{SO}_{4}$ at 1: 4 soil to extractant ratio (Vance et al., 1987). Microbial biomass $\mathrm{N}$ was calculated as the difference in $\mathrm{NH}_{4}^{+}$concentration between fumigated and non-fumigated samples divided by 0.57 , which is the proportionality factor to convert ammonium to MBN suggested by Moore et al. (2000). Microbial biomass P (MBP) was determined with the anion exchange method as described by Kouno et al. (1995) using hexanol as fumigant. Microbial biomass $\mathrm{P}$ is the difference in $\mathrm{P}$ concentration between fumigated and unfumigated soil (Kouno et al., 1995). No correction factor was used for $\mathrm{P}$ because recovery of a P spike in this soil was $98 \%$ (Butterly et al., 2010).

\subsection{Statistical analysis}

There were four replicate cores for each treatment and sampling time. Data was tested for homogeneity and equal variance. One-way ANOVA was used to compare the properties of two plant residues. For measurements carried out repeatedly during the experiment, repeated measures analysis of variance (ANOVA) was carried out in GenStat (GenStat for Windows, $15^{\text {th }}$ edition, VSN Int. Ltd, UK, 2012). Two-way ANOVA with factors residue $\mathrm{x}$ moisture treatment was used for data in the first 10 days, two-way ANOVA with factors residue and moisture treatment $\mathrm{x}$ day of residue addition for data after the second residue addition. The interaction of residue treatment and time of the second residue addition was significant $(\mathrm{p}<0.05)$. Therefore, Tukey's multiple comparison test at $95 \%$ confidence interval was used for each sampling time separately to determine which treatments differ significantly from each other. In the results, only significant differences are reported.

\section{Results}

\subsection{Respiration}

In the first three days after the first residue addition, respiration rate was highest in LH-50 (low $\mathrm{C} / \mathrm{N}$ young faba bean followed by high $\mathrm{C} / \mathrm{N}$ wheat straw at 50\% WHC) and lowest in HL-10 (high $\mathrm{C} / \mathrm{N}$ wheat straw followed by low $\mathrm{C} / \mathrm{N}$ young faba bean at $10 \%$ WHC) (Figure 1a). Within each residue treatment, it was lower with $10 \%$ WHC than $50 \%$ WHC, with greater differences in LH than HL. In LH, respiration rate declined in the first 6 days whereas in HL50, respiration rate increased from $\mathrm{d} 2$ to $\mathrm{d} 5$ and then decreased. Rewetting of the $10 \%$ WHC treatments on d10 induced a ten-fold increase in respiration rate on $\mathrm{d} 11$, after which respiration rate decreased until it was similar to that in $50 \%$ WHC treatments on $\mathrm{d} 15$.

After the second residue addition, respiration rate was influenced by timing of amendment and in LH, water content in the first 10 days (Figure 1b, c, d, e). In LH, respiration rate between the second and fourth day after amendment was highest when residue was added five days after rewetting (Figure 1b, c). When residue was added one day after rewetting, respiration rate decreased from $\mathrm{d} 1$ to $\mathrm{d} 2$ after which it remained stable until $\mathrm{d} 6$ and then decreased. In the treatment where the second residue was added two days after rewetting, respiration rate increased until d5 and then decreased.

In HL, respiration rate was highest on $\mathrm{d} 1$ when the second residue was added five days after rewetting (Figure 1d, e). Respiration rate declined from d2 and was little affected by when the residue was added from $\mathrm{d} 4$ onwards. Respiration rate was not influenced by water content in the first 10 days. 
Cumulative respiration in the first 10 days was higher at $50 \%$ WHC than at $10 \%$ (Figure 2a). Only at 50\% WHC it was higher in LH than HL. Cumulative respiration between rewetting and the second residue addition increased with number of days (Figure 2b, c, d). In the 10 days after the second residue addition, cumulative respiration was higher when residue was added five days was rewetting than if added after one or two days. Cumulative respiration after rewetting and residue addition was greater in soil kept at $10 \%$ WHC in the first ten days than with $50 \%$. It was higher in HL than LH, with greater differences at $50 \%$ than $10 \%$ WHC.
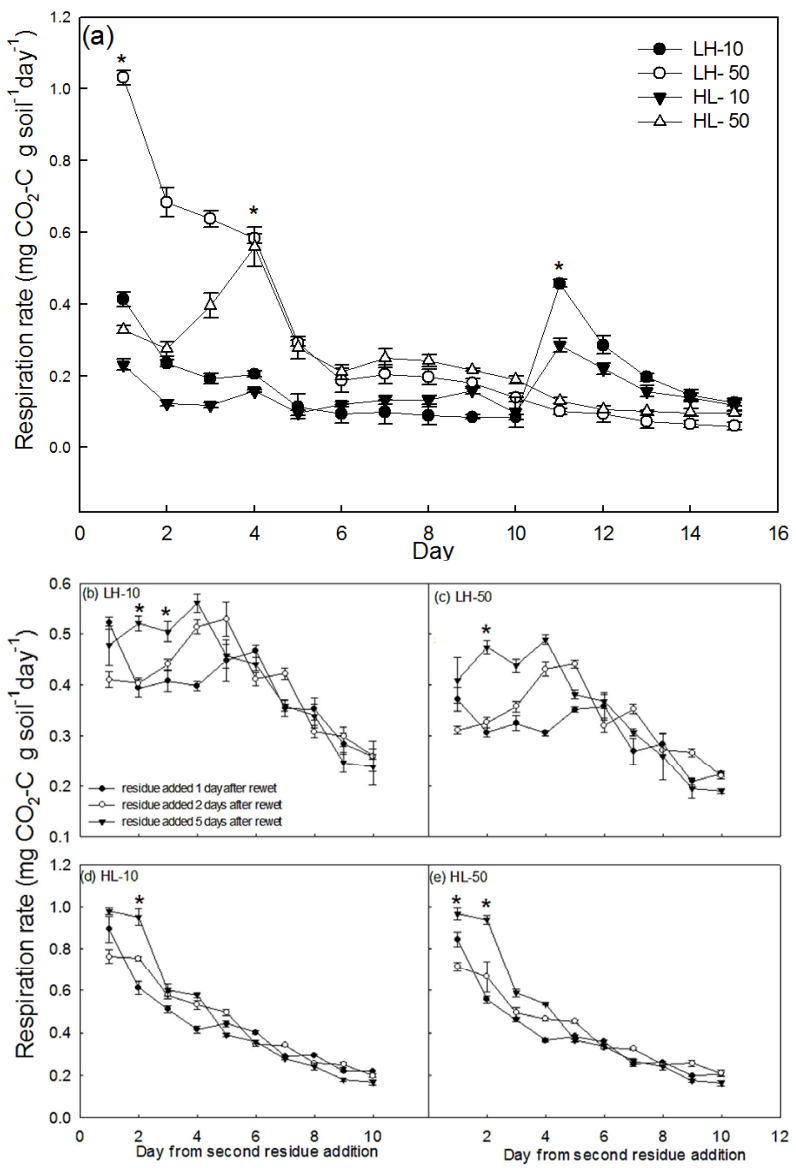

Figure 1. Respiration rate ( $\mathrm{n}=4$, means \pm SE) from day 1 to 15 in treatments $\mathrm{LH}$ and $\mathrm{HL}$ at $10 \%$ or $50 \% \mathrm{WHC}$ in the first 10 days (LH-10, LH-50, HL-10 and HL-50) (a); respiration rate in the 10 days after the second residue addition with residue added 1, 2 or 5 days after rewet in LH-10 (b), LH-50 (c), HL-10 (d) and HL-50 (e). (n=4, means $\pm \mathrm{SE})$. Asterisks were added where there was significant differences among treatments $(P \leq 0.05)$. 


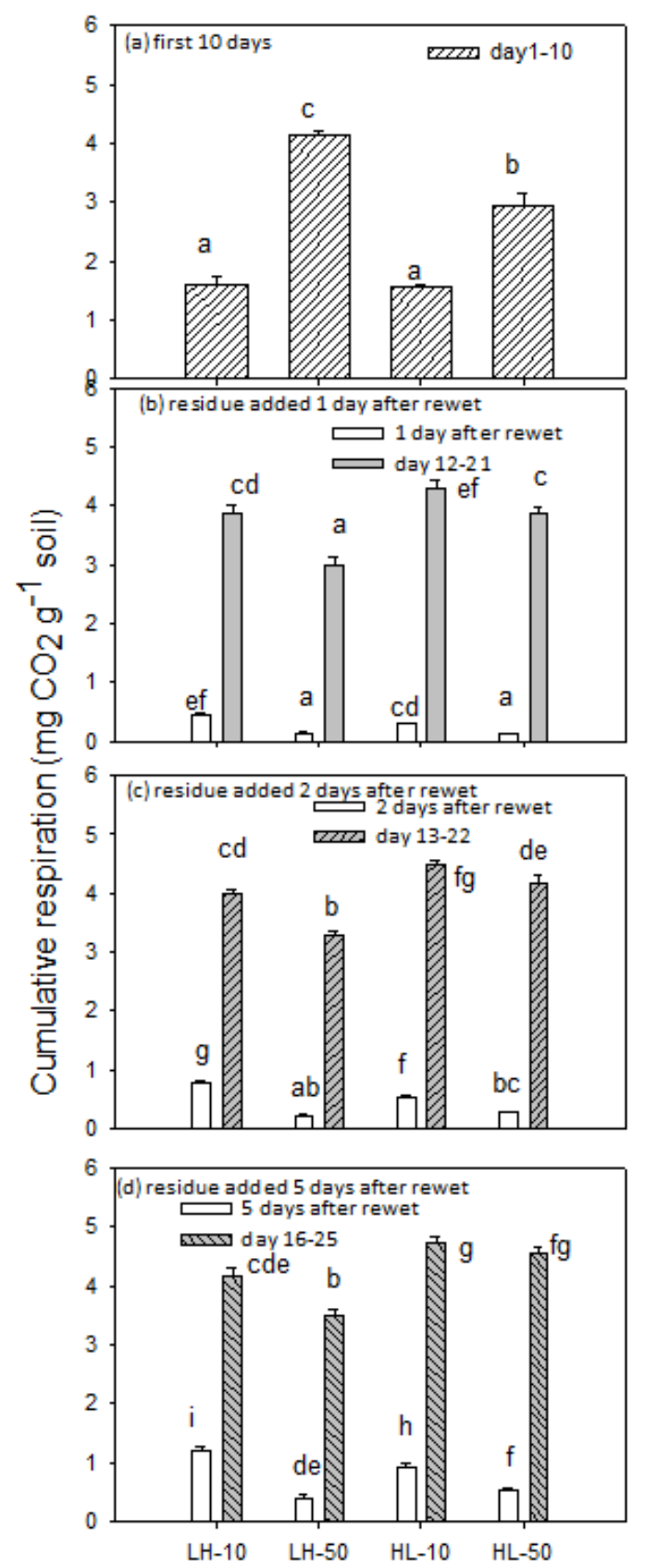

Figure 2. Cumulative respiration from day 1 to 10 in treatments LH and HL at $10 \%$ or $50 \%$ WHC (LH-10, LH50, HL-10 and HL-50 ( $\mathrm{n}=4$, means $\pm \mathrm{SE}$ ) (a). Cumulative respiration after rewet before and after residue addition with residue added 1 (b), 2 (c) or 5 days after rewet (d). 


\subsection{Microbial biomass}

Two days after the first residue addition, MBN was two-fold higher at $50 \%$ WHC than at $10 \%$, but did not differ between residue treatments at a given water content (Figure 3a). From d2 to d10, MBN increased in LH, but decreased in HL (Figure 3b). On d10, MBN was up to ten-fold higher in LH than $\mathrm{HL}$ and it was higher at $50 \% \mathrm{WHC}$ than at $10 \%$. After rewetting and before the second residue addition, MBN in LH was lower after one day than after five days (Figure $3 c)$. Time after rewetting had no consistent effect on
MBN in HL. In general, MBN was higher in LH than HL, but was not influenced by the water content in the first ten days. Two days after the second amendment, MBN was highest when the second residue was added one day after rewetting (Figure 3d). In both residue treatments, MBN was lower with $50 \%$ WHC in the first ten days than with $10 \%$. Ten days after the second amendment, MBN in most treatments except in HL50 , was two to five-fold higher if the second residue was added one day after rewetting than if it was added after five days (Figure 3e). There were no consistent differences in MBN between HL and LH.
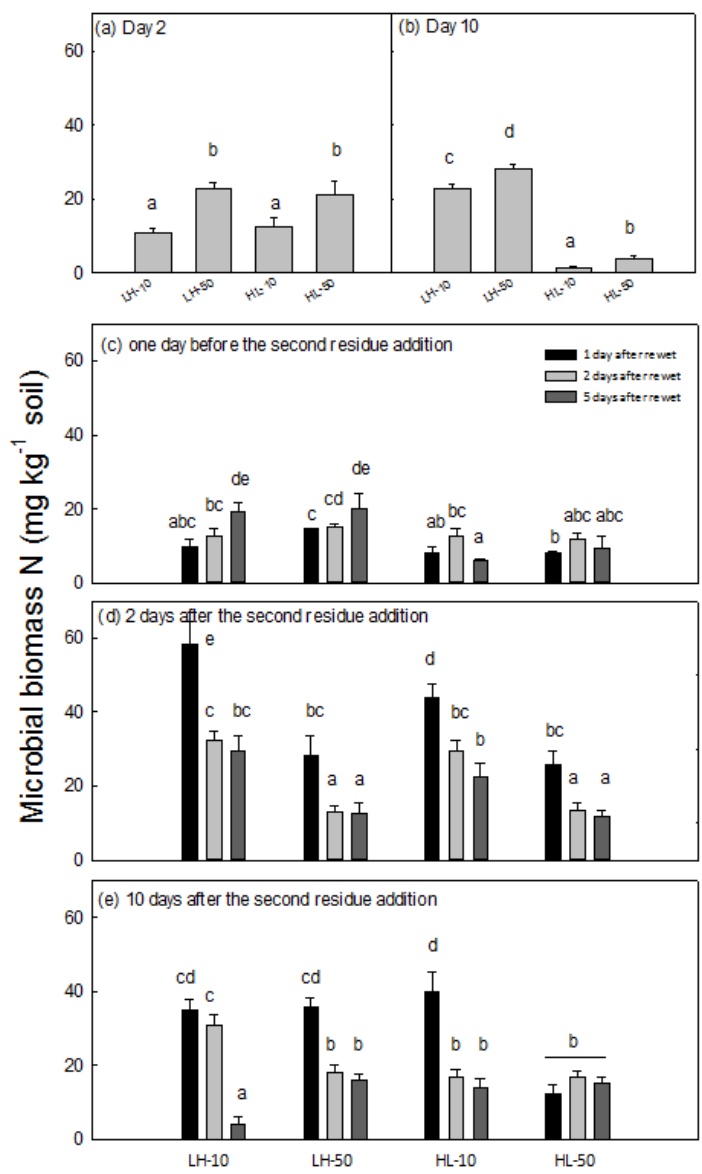

Figure 3. Microbial biomass $\mathrm{N}$ in treatments LH-10, LH-50, HL-10 and HL-50 on days 2 (a) and 10 (b), first day after rewet and before second residue addition (c), and 2 days (d) and 10 days after second residue addition (e) $(n=4$, means \pm SE). Bars with different letters indicate significant differences among treatments at each sampling time $(P \leq 0.05)$. 
On d2 after the first residue addition, MBP was about ten-fold higher in $\mathrm{LH}$ than $\mathrm{HL}$ at both water contents (Figure 4a). From d2 to d10, MBP decreased in LH, but increased in HL. On d10, MBP was higher in LH-50 than in the other treatments (Figure 4b). After rewetting and before the second residue addition, MBP decreased with number of days after rewetting in LH-10, but did not change over time in the other treatments (Figure 4c). Residue treatment and water content in the first ten days had little effect on MBP before and after the second residue addition. The number of days between rewetting and second amendment did not influence MBP after the second residue addition.

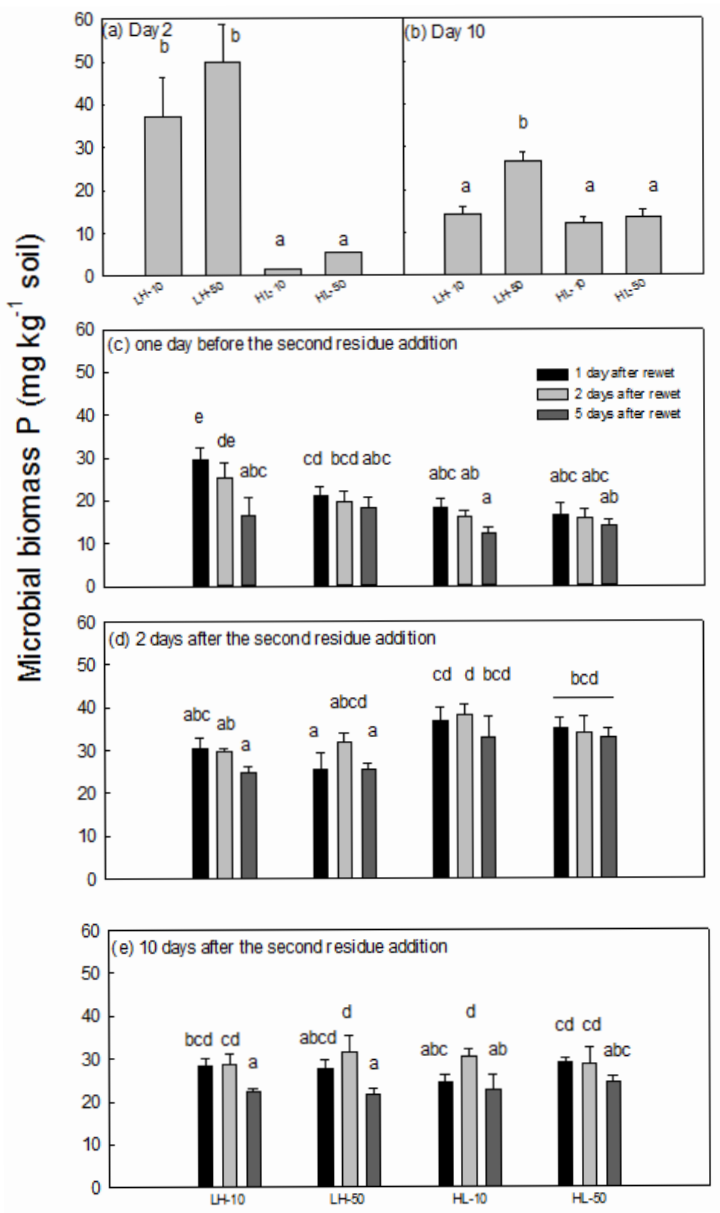

Figure 4. Microbial biomass P concentration in treatments LH-10, LH-50, HL-10 and HL-50 on days 2 (a), 10 (b), first day after rewet and before second residue addition (c), and 2 days (d) and 10 days after second residue addition (e) $(\mathrm{n}=4$, means $\pm \mathrm{SE})$. At a given sampling time, bars with different letters are significantly different $(P \leq 0.05)$. 


\subsection{Available $N$ and $P$}

Available $\mathrm{N}$ on $\mathrm{d} 2$ and $\mathrm{d} 10$ after the first residue addition was about two-fold higher in LH than HL (Figure $5 \mathrm{a}, \mathrm{b}$ ). On $\mathrm{d} 2$, available $\mathrm{N}$ was slightly, but significantly higher at $10 \% \mathrm{WHC}$ than at $50 \%$. On d10, available $\mathrm{N}$ in $\mathrm{LH}$ was higher at $50 \% \mathrm{WHC}$ than at $10 \%$, but not in HL. After rewetting and before the second amendment, available $\mathrm{N}$ was three to four-fold higher in LH than HL. In LH, available $\mathrm{N}$ was lower one day after rewetting than five days after rewetting. After five days it was higher in soil that had been at $10 \%$ WHC in the first 10 days than the soil at 50\% WHC (Figure 5c). In HL, available $\mathrm{N}$ was not influenced by the previous water content or time after rewetting. Two days after the second amendment, available $\mathrm{N}$ was about $40 \%$ higher in $\mathrm{HL}$ than LH (Figure 5d). In all treatments, available $\mathrm{N}$ was highest when the second residue had been added 5 days after rewetting. Available N was higher in HL50 than HL-10, but water content in the first 10 days did not influence available $\mathrm{N}$ in LH. Ten days after the second residue addition, available $\mathrm{N}$ was higher in $\mathrm{HL}$ than LH, but there was no consistent effect of water content in the first ten days or number of days between rewetting and second residue addition (Figure 5e).
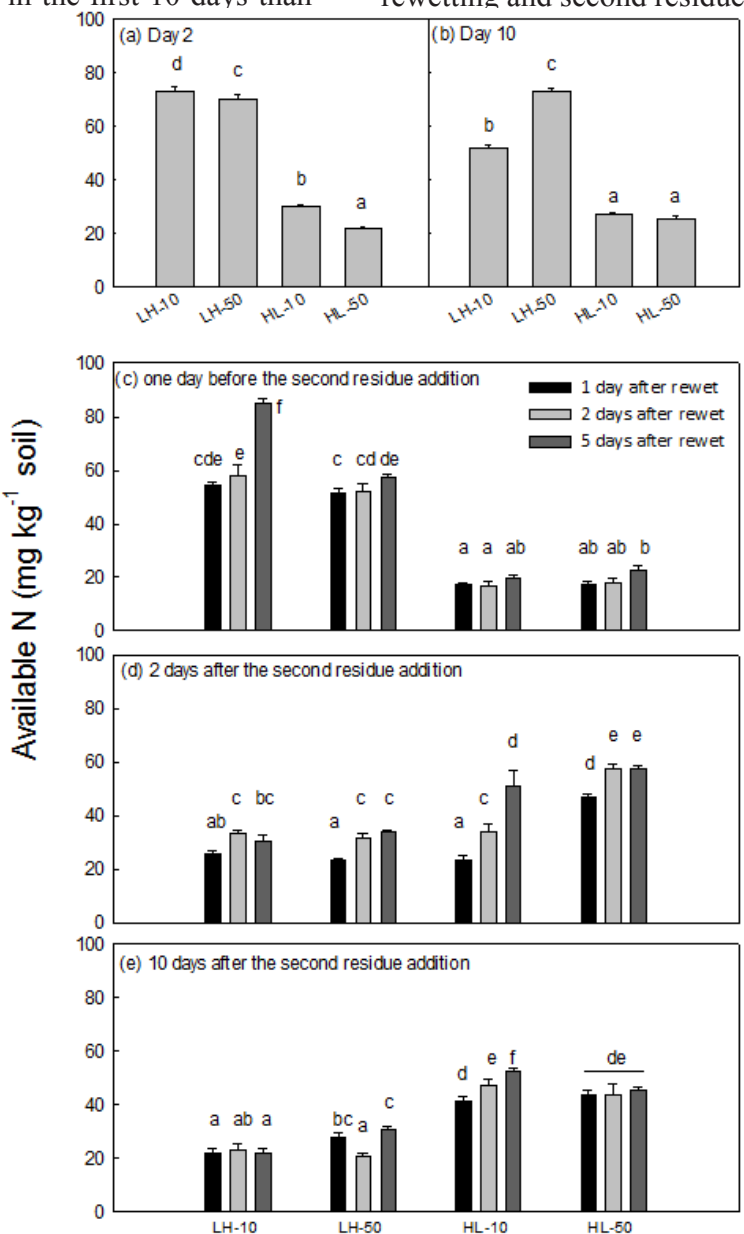

Figure 5. Available N concentration in treatments LH-10, LH-50, HL-10 and HL-50 on days 2 (a) and 10 (b), first day after rewet and before second residue addition (c), and 2 days (d) and 10 days after second residue addition (e) (n=4, means $\pm \mathrm{SE})$. At a given sampling time, bars with different letters are significantly different $(P \leq 0.05)$. 
Two and ten days after the first residue addition, available $\mathrm{P}$ was about two-fold higher in $\mathrm{LH}$ than HL (Figure 6a, b). Water content had little effect on available $\mathrm{P}$ except on $\mathrm{d} 10$ in $\mathrm{LH}$ where it was higher at $10 \% \mathrm{WHC}$ than at $50 \%$. After rewetting and before the second amendment, available $\mathrm{P}$ was more than two-fold higher in LH than HL (Figure 6c). Neither water content in the first ten days nor time after rewetting influenced available $\mathrm{P}$. Two days after the second amendment, available $\mathrm{P}$ was highest in HL-50 (Figure 6d). The water content in the first ten days influenced available $\mathrm{P}$ only in $\mathrm{HL}$ where it was higher in HL-50 than HL-10. Ten days after the second residue addition, available $\mathrm{P}$ was about $20 \%$ higher in HL than LH (Figure 6e). Two and ten days after the second residue addition, available $\mathrm{P}$ was not influenced by the number of days between rewetting and residue addition.

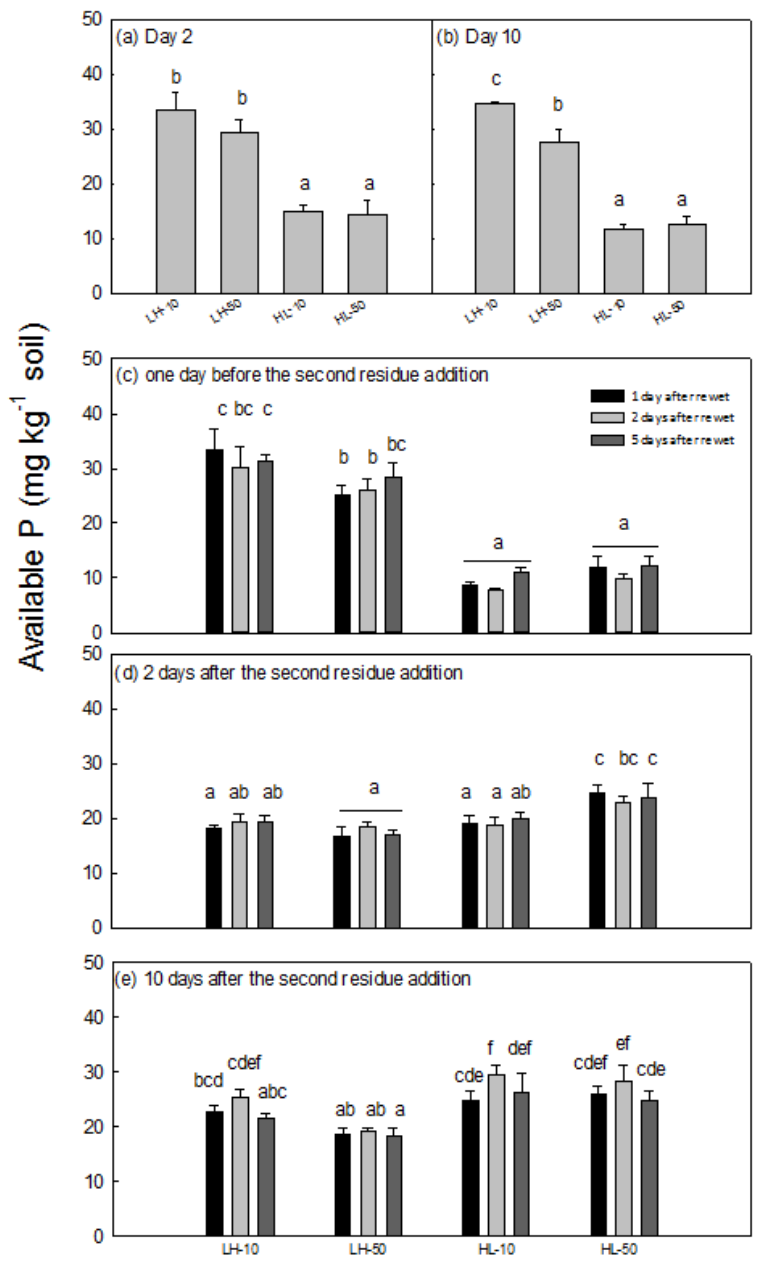

Figure 6. Available P concentration in treatments LH-10, LH-50, HL-10 and HL-50 on days 2 (a) and 10 (b), day after rewet and before second residue addition (c), and 2 days (d) and 10 days after second residue addition (e) $(n=4$, means \pm SE). At a given sampling time, bars with different letters are significantly different $(P \leq 0.05)$. 


\section{Discussion}

In this study, the soil water content between the first and second plant residue addition influenced respiration whereas the time between rewetting and residue addition affected $\mathrm{N}$ availability. Microbial $\mathrm{N}$ uptake was influenced by both soil water content and time between rewetting and residue addition. However, neither soil water content between the first and second residue addition nor time between rewetting and residue addition influenced the legacy effect.

\subsection{First ten days}

Low water content $(10 \% \mathrm{WHC})$ reduced cumulative respiration as well as MBN on $\mathrm{d} 2$ and $\mathrm{d} 10$ compared to $50 \%$ WHC. Reduced microbial activity at low soil water content is due to restricted water availability and disconnection of the water film around aggregates, which limits substrate diffusion to microbes (Schimel et al., 2007). However, cumulative respiration at $10 \%$ WHC was half of that at $50 \%$, but not eliminated, which suggests that some microbial growth occurred at this low water content (Zhang and Marschner, 2017). Available $\mathrm{N}$ decreased from $\mathrm{d} 2$ to $\mathrm{d} 10$ in LH-10 indicating that $\mathrm{N}$ immobilisation exceeded $\mathrm{N}$ mineralisation at low water content. As expected from previous studies (Hadas et al., 2004; Marschner et al., 2015), the lower $\mathrm{C} / \mathrm{N}$ ratio of $\mathrm{L}$ induced higher available $\mathrm{N}$ and $\mathrm{P}$ compared to $\mathrm{H}$.

\subsection{Between rewetting and second residue addition}

The greater cumulative respiration after rewetting in the soil that had been at $10 \%$ WHC in the first 10 days compared to that at $50 \% \mathrm{WHC}$ can be explained by the rewetting flush that has been documented in many previous studies (Schimel et al., 2007; Borken and
Matzner, 2009; Shi and Marschner, 2014). However, the previous water content had little effect on nutrient availability and microbial biomass after rewetting. The number of days between rewetting and residue addition influenced microbial biomass and $\mathrm{N}$ availability in LH-10. Five day after rewetting compared to one day, MBN and available $\mathrm{N}$ were higher. This suggests that with time after rewetting, more substrate became available allowing microbial $\mathrm{N}$ uptake and releasing available $\mathrm{N}$ from the low $\mathrm{C} / \mathrm{N}$ residue added on $\mathrm{d} 0$. MBN increased from the first to the fifth day in both LH-10 and LH-50, thus was related to time after the first residue addition, not rewetting. However, available $\mathrm{N}$ increased with time only in LH-10. This suggests that rewetting induced $\mathrm{N}$ mineralisation beyond the requirement of the microbes (Mikha et al., 2005). In HL, time after rewetting did not influence microbial biomass or nutrient availability, probably because the low nutrient content of the $\mathrm{H}$ residues in the soil limited respiration, growth and nutrient mineralisation (Heal et al., 1997).

\subsection{After second residue addition}

Respiration rate in the first three to four days after the second residue addition were higher when residue was added five days after rewetting compared to one day, particularly in LH. This stimulated respiration suggests that microbes were more starved five days after rewetting (Zhang and Marschner, 2017) (15 days after the first amendment) and rapidly decomposed the freshly added residues. Cumulative respiration was greater in HL than LH which can be explained by the addition of easily decomposable L on day 10 in the former. The higher cumulative respiration in LH-10 and HL-10 compared to LH-50 and HL50 shows that rewetting can stimulate respiration 
for more than five days in residue amended soil. In a non-amended soil, the rewetting flush may be shorter-lived because of rapid depletion of available nutrients (Borken and Matzner, 2009).

Two days after the second residue addition, the previous water content influenced microbial $\mathrm{N}$ uptake in both residue treatments. Rewetting of the soil that had been at $10 \%$ WHC in the first ten days increased $\mathrm{MBN}$ compared to the soil maintained at $50 \%$ WHC. In LH, $\mathrm{N}$ taken up by microbes may have come from the $\mathrm{L}$ residue left in the soil from the first addition. In HL microbes likely mineralised the freshly added L. However, $\mathrm{N}$ availability was not influenced by the previous water content indicating that rewetting only increased microbial $\mathrm{N}$ uptake, not net $\mathrm{N}$ mineralisation. Residue type influenced available $\mathrm{N}$ and $\mathrm{P}$ only in soil that was at $50 \%$ in first ten days, where it was greater in HL than LH which can be explained by the addition of low $\mathrm{C} / \mathrm{N}$ residue in HL two days before (Heal et al., 1997). In the soil that was at $10 \%$ WHC in the first 10 days, it is likely that in LH sufficient $\mathrm{L}$ was left in the soil when $\mathrm{H}$ was added to induce net $\mathrm{N}$ and $\mathrm{P}$ mineralisation to a similar extent as in HL where L had just been added. The first hypothesis was that the legacy effect of the first residue added would be greater when the soil water content between first and second residue addition is low. A greater legacy effect would reduce the effect of the second residue added on the measured parameters. For example in $\mathrm{LH}$, available $\mathrm{N}$ after the second residue addition should be higher in soil previously at $10 \% \mathrm{WHC}$ than that kept at $50 \%$ WHC. However, the water content in the first 10 days had no consistent effect on the legacy effect. Therefore, we decline the hypothesis.

The number of days between rewetting and second amendment influenced MBN two days and 10 days after the second residue addition in all treatments. In treatments with residues added one day after rewetting, MBN was higher compared to amendment after five days. Since this occurred irrespective of the water content in the first 10 days, the higher MBN when residues were added one day after rewetting can be explained by the time between first and second residue addition: 10 compared to 15 days. A shorter interval between residue additions appears to stimulate $\mathrm{N}$ uptake by the microbial biomass. In $\mathrm{N}$ limiting conditions, the number of days between rewetting and residue addition may have little effect on MBN and available N. However, the number of days between rewetting and the second residue amendment did not influence legacy effect. Thus, the second hypothesis can be declined.

\section{Conclusion}

This study showed that in plant residue amended soil, $\mathrm{N}$ mineralisation and immobilisation are influenced by soil water content after the first residue addition and time between rewetting and second residue addition. The new finding is that two and 10 days after the second residue addition, MBN was higher in soil that was amended one day after rewetting than that amended after five days which indicates enhanced $\mathrm{N}$ immobilisation. Enhanced microbial $\mathrm{N}$ uptake may reduce plant $\mathrm{N}$ availability, but can also minimise $\mathrm{N}$ loss via leaching or volatilisation. Further, the immobilised $\mathrm{N}$ becomes plant available over time through microbial biomass turnover. This indicates that the interval between residue additions should be taken into account in farming systems. To better understand $\mathrm{N}$ dynamics in residue amended soil after rewetting and its impact on plant $\mathrm{N}$ uptake ${ }^{15} \mathrm{~N}$ labelled residue should be used in future experiments. 


\section{Acknowledgements}

Yanchen Zhang received a scholarship from The University of Adelaide.

\section{References}

Birch, H.F. 1958. The effect of soil drying on humus decomposition and nitrogen availability. Plant Soil. 10(1), 9-31.

Borken, W., Egbert M. 2009. Reappraisal of drying and wetting effects on $\mathrm{C}$ and $\mathrm{N}$ mineralization and fluxes in soils. Global Change Biol. 15(4), 808824.

Bremmer, J.M., Mulvaney, C.S. 1982. Total N. Methods of Soil Analysis. Part2. 2nd ed. Agron. Monog 9, 895-926.

Butterly, C.R., Marschner, P., McNeill, A.M., Baldock, J.A. 2010. Rewetting $\mathrm{CO}_{2}$ pulses in Australian agricultural soils and the influence of soil properties. Biol fert soils. 46(7), 739-753.

Chaudhari, S.K., Singh, R., Kundu, D.K. 2008. Rapid textural analysis for saline and alkaline soils with different physical and chemical properties. Soil Sci Soc Am J. 72(2), 431-441.

Hadas, A., Kautsky, L., Goek, M., Kara, E.E. 2004. Rates of decomposition of plant residues and available nitrogen in soil, related to residue composition through simulation of carbon and nitrogen turnover. Soil Biol Biochem. 36(2), 255266 .

Heal, O.W., Anderson, J.M., Swift, M.J. 1997. Plant litter quality and decomposition: an historical overview. Driven by nature: plant litter quality and decomposition. Ed. G. Cadisch. CABI.

IPCC, AR. 2007. Intergovernmental panel on climate change. IPCC Secretariat Geneva.
Isbell, R. 2002. The Australian soil classification, 4. CSIRO publishing.

Kettler, T.A., Doran, J.W., Gilbert, T.L. 2001 Simplified method for soil particle-size determination to accompany soil-quality analyses. Soil Sci Soc Am J. 65(3), 849-852.

Kouno, K., Tuchiya, Y., Ando, T. 1995. Measurement of soil microbial biomass phosphorus by an anion exchange membrane method. Soil Biol Biochem. 27(10), 1353-1357.

Marschner, P., Hatam, Z., Cavagnaro, T.R. 2015. Soil respiration, microbial biomass and nutrient availability after the second amendment are influenced by legacy effects of prior residue addition. Soil Biol Biochem. 88, 169-177.

Mikha, M.M., Rice, C.W., Milliken, G.A., 2005 Carbon and nitrogen mineralization as affected by drying and wetting cycles. Soil Biol Biochem. 37(2), 339-347.

Miranda, K.M., Espey, M.G., Wink, D.A. 2001. A rapid, simple spectrophotometric method for simultaneous detection of nitrate and nitrite. Nitric oxide. 5(1), 62-71.

Moore, J.M., Klose, S., Tabatabai, M.A. 2000. Soil microbial biomass carbon and nitrogen as affected by cropping systems. Biol. Fert. Soils. 31(3-4), 200-210.

Murphy, J., Riley, J.P. 1962. A modified single solution method for the determination of phosphate in natural waters. Analytica chimica acta. 27, 31-36.

Nguyen, T.T., Ngo, H.T.T., Marschner, P. 2016. Legacy effect of previous residue additioninfluence of length of the moist period between residue additions on soil respiration, microbial biomass and nutrient availability. Biol. Fert. Soils. 1-11. 
Nye, P.H. 1966. The effect of the nutrient intensity and buffering power of a soil, and the absorbing power, size and root hairs of a root, on nutrient absorption by diffusion. Plant Soil. 25(1), 81105.

Power, A.G. 2010. Ecosystem services and agriculture: tradeoffs and synergies. Philosophical transactions of the royal society B: biological sciences. 365, 2959-2971.

Schimel, J., Balser, T.C., Wallenstein, M. 2007. Microbial stress-response physiology and its implications for ecosystem function. Ecology. 88(6), 1386-1394.

Scotti, R., Bonanomi, G., Scelza, R., Zoina, A., Rao, M.A. 2015. Organic amendments as sustainable tool to recovery fertility in intensive agricultural systems. J. soil sci. plant nutr. 15(2), 333-352.

Setia, R., Marschner, P., Baldock, J., Chittleborough, D., Smith, P., Smith, Jo. 2011. Salinity effects on carbon mineralization in soils of varying texture. Soil Biol. Biochem. 43(9), 1908-1916.

Shi, A., Marschner, P. 2014. Drying and rewetting frequency influences cumulative respiration and its distribution over time in two soils with contrasting management. Soil Biol. Biochem. 72, 172-179.

Vance, E.D., Brookes, P.C., Jenkinson, D.S. 1987. An extraction method for measuring soil microbial biomass C. Soil Biol. Biochem. 19(6), 703-707.
Walkley, A., Black, I.A. 1934. An examination of the Degtjareff method for determining soil organic matter, and a proposed modification of the chromic acid titration method. Soil Sci. 37(1), 29-38.

Willis, R.B., Montgomery M.E., Allen P.R. 1996. Improved method for manual, colorimetric determination of total Kjeldahl nitrogen using salicylate. J. Agri. Food Chem. 44(7), 1804-1807.

Xue, R., Shen, Y., Marschner, P. 2016. Low soil water content during plant growth influences soil respiration and microbial biomass after plant removal and rewetting. J. Soil Sci. Plant Nutr. 16(4), 955-966.

Zhang, Y., Marschner, P. 2016. Nutrient availability, soil respiration and microbial biomass after the second residue addition are influenced by the $\mathrm{C} / \mathrm{N}$ ratio of the first residue added, but not by drying and rewetting between residue amendments. Euro. J. Soil Biol. 77, 68-76.

Zhang, Y., Marschner, P. 2017. Soil amendment with high and low $\mathrm{C} / \mathrm{N}$ residue - influence of low soil water content between first and second residue addition on soil respiration, microbial biomass and nutrient availability. J. Soil Sci. Plant Nutr. 17(3), 594-608.

Zheng, B., Marschner, P. 2017. Previous residue addition rate and $\mathrm{C} / \mathrm{N}$ ratio influence nutrient availability and respiration rate after the second residue addition. Geoderma. 285, 217-224. 